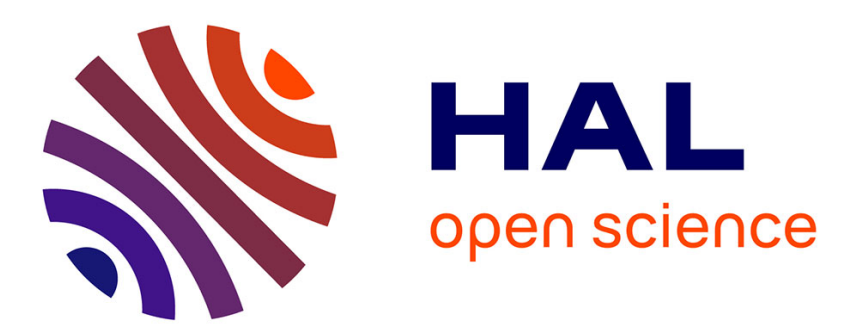

\title{
Polymerization of 2-(hydroxyethyl)methacrylate by two different initiator/accelerator systems: a Raman spectroscopic monitoring
}

Guillaume Mabilleau, Corneliu Cincu, Michel-Félix Baslé, Daniel Chappard

\section{- To cite this version:}

Guillaume Mabilleau, Corneliu Cincu, Michel-Félix Baslé, Daniel Chappard. Polymerization of 2(hydroxyethyl)methacrylate by two different initiator/accelerator systems: a Raman spectroscopic monitoring. Journal of Raman Spectroscopy, 2008, 39 (7), pp.767 - 771. 10.1002/jrs.1960 . hal03261972

\section{HAL Id: hal-03261972 \\ https://univ-angers.hal.science/hal-03261972}

Submitted on 16 Jun 2021

HAL is a multi-disciplinary open access archive for the deposit and dissemination of scientific research documents, whether they are published or not. The documents may come from teaching and research institutions in France or abroad, or from public or private research centers.
L'archive ouverte pluridisciplinaire HAL, est destinée au dépôt et à la diffusion de documents scientifiques de niveau recherche, publiés ou non, émanant des établissements d'enseignement et de recherche français ou étrangers, des laboratoires publics ou privés. 


\title{
Polymerization of 2-(hydroxyethyl)methacrylate by two different initiator/accelerator systems: a Raman spectroscopic monitoring
}

\author{
G. Mabilleau, ${ }^{1}$ C. Cincu ${ }^{1,2}$ M. F. Baslé ${ }^{1}$ and D. Chappard ${ }^{1 *}$ \\ ${ }^{1}$ INSERM, U922 - LHEA, Faculté de Médecine, 49045 ANGERS Cédex, France \\ 2 University Politehnica, Industrial Chemistry Faculty, Department of Macromolecular Chemistry, Bucharest, RO-71101 Romania \\ Received 16 January 2008; Accepted 5 February 2008
}

\begin{abstract}
The control of monomer polymerization is important when preparing biocompatible devices. The compound 2-(hydroxyethyl)methacrylate can be polymerized by redox systems using benzoyl peroxide (BPO) (as accelerator) and a substituted amine (as initiator). However, this system is associated with a highly exothermic polymerization, and end-products with inflammatory properties are produced. We have used ascorbic acid (AA) to induce BPO fragmentation and have compared the kinetics of the reaction, by Raman microscopy, with that obtained with a substituted amine. The breaking of the $\mathrm{C}=\mathrm{C}$ bond (Raman stretching vibration at $1641 \mathrm{~cm}^{-1}$ ) could be monitored in both cases and reflected the incorporation of new monomer molecules into the chain. The AA-induced polymerization was slower than with the substituted amine and was accompanied by the appearance of a new band at $1603 \mathrm{~cm}^{-1}$, assigned to the stretching vibrations of $-\mathrm{COOH}$ species incorporated into the chains. Raman microscopy appears to be a powerful tool in the study of polymeric biomaterial preparation. Copyright $\odot 2008$ John Wiley \& Sons, Ltd.
\end{abstract}

KEYWORDS: Raman microscopy; pHEMA; ascorbic acid; benzoyl peroxide

\section{INTRODUCTION}

Methacrylic polymers and copolymers are widely used for medical applications such as in dentistry, bone cements and biomaterials. Among them, poly(2-(hydroxyethyl) methacrylate) (pHEMA) is favored for preparing intraocular lenses, microbeads for vascular embolization, immobilization of cells, enzymes or pharmacological drugs. ${ }^{1}$ The polymer can also represent an interesting bone substitute. ${ }^{2-4}$ The monomer (HEMA) is fully soluble in water and can be polymerized at low temperatures (from -20 to $+10^{\circ} \mathrm{C}$ ) by controlling the exothermicity during the redox polymerization steps, thereby preserving the biochemical activity of cell enzymes. The hydroxyethyl pending species of the polymer confer high hydrophilicity, good biocompatibility and the possibility to prepare pHEMA in the form of a hydrogel. Poly-HEMA is usually bulked-polymerized by redox systems; the most frequently used methods imply azobisisobutyronitrile (AIBN) or the couple benzoyl peroxide (BPO) and a substituted amine. HEMA polymerization proceeds via an addition reaction that is composed of the three

*Correspondence to: D. Chappard, INSERM, U922 - LHEA, Faculté de Médecine, 49045 ANGERS Cédex, France.

E-mail: daniel.chappard@univ-angers.fr following steps: initiation, propagation and termination. The initiation stage of polymerization implies the breakdown of AIBN (by heat) or the peroxide (by the amine) to produce free radicals $\left(R^{\bullet}\right)$. These radicals, in turn, react with the $C=C$ double bond of the monomer molecules to form a new radical $\mathrm{R}-\mathrm{CH}_{2}-\mathrm{CH}^{\bullet}$, which is more stable and reactive. This active center can react with a new HEMA molecule, thereby allowing propagation and extension of the polymer chain. This step is associated with a temperature rise in the bulk mixture due to the exothermic opening of the $\mathrm{C}=\mathrm{C}$ bond $(50 \mathrm{~kJ} / \mathrm{mol}) .^{5}$ During propagation, more and more HEMA monomer molecules are added to the existing polymer chains. As unreacted molecules gradually become depleted in the bulk, the resultant polymer becomes more and more viscous (a phenomenon known as the Trommsdorf's effect) and termination reactions (combination or disproportionation) occur progressively, and heat is dissipated into the surroundings. ${ }^{6}$

Raman microscopy is a useful method to observe polymerization of vinyl monomers in situ since characteristic bands either of the monomer or of the polymer can change in intensity during the progress of polymerization. The $\mathrm{C}=\mathrm{C}$ group exhibits characteristic vibrational peaks that can be used for monitoring polymerization. In the present study, Raman microscopy 
was used to monitor HEMA polymerization induced by using two different initiator systems: $\mathrm{BPO} / N, N$ dimethylparatoluidine (NN-DMPT) and a less toxic ascorbicbased system.

\section{EXPERIMENTAL}

Commercial 2-(hydroxyethyl)methacrylate was purchased from Sigma-Aldrich Chemicals (Illkirsh, France). Commercial HEMA contains residual methacrylic acid and crosslinkers due to the manufacturing process. The polymerization inhibitor 4-methoxyphenol (added by the manufacturer before shipping, at a concentration of $350 \mathrm{ppm}$ ) also needs to be removed. HEMA was purified and distilled under reduced pressure $\left(5 \times 10^{-2} \mathrm{mbar}, 65^{\circ} \mathrm{C}\right)$. Other chemicals were used as received.

\section{Polymerization process}

The polymer was prepared by bulk polymerization. Two different couples of accelerator/initiator were used: $N N$ $\mathrm{DMPT} / \mathrm{BPO}$ and ascorbic acid (AA)/BPO. Briefly, the polymerization mixture was composed of HEMA (2 ml) and $0.069 \mathrm{~g}$ of BPO. The reaction was accelerated by $N N-$ DMPT or AA in molar ratios $\mathrm{BPO} /$ initiator of $500: 1$ and $1: 2(\mathrm{~mol} / \mathrm{mol})$, respectively. Polymerization was carried on at room temperature with the NN-DMPT/BPO system or at $37^{\circ} \mathrm{C}$ with the $\mathrm{AA} / \mathrm{BPO}$ system in polypropylene wells ( $9 \mathrm{~mm}$ diameter, $2 \mathrm{~mm}$ height). The kinetics of polymerization was recorded by Raman microscopy on six disks for each accelerator/initiator couple. The chemical reaction of BPO fragmentation by AA is described in Fig. 1.

\section{Raman microscopy}

Raman analysis was performed on a Sentera microscope with the OPUS 5.5 software (Bruker Optik, Ettlingen, Germany). The excitation laser wavelength was $785 \mathrm{~nm}$. The long working distance of the $\times 20$ microscope objective gave a spot size in the order of $\sim 2 \mu \mathrm{m}$. Values from intensities and bandwidths of the peaks recorded on the spectrum were used as described in the literature. ${ }^{7,8}$ Four bands were investigated: $\mathrm{C}=\mathrm{CH}_{2}$ stretching at $1407 \mathrm{~cm}^{-1}, \mathrm{C}-\mathrm{H}$ deformation at $1455 \mathrm{~cm}^{-1}, \mathrm{C}=\mathrm{C}$ stretching at $1641 \mathrm{~cm}^{-1}$ and
(A) benzoyl peroxide

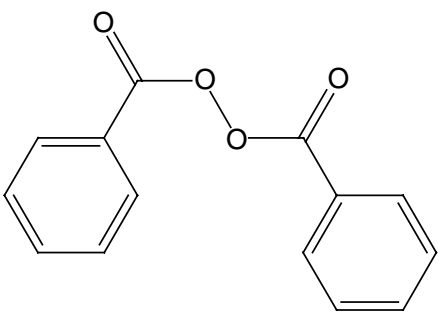

ascorbic acid<smiles>CCCCCCCO</smiles><smiles>O=C([O-])c1ccccc1</smiles><smiles>O=C(O)c1ccccc1</smiles><smiles>O=C1C(O)=C([O-])O[C@H]1[C@@H](O)CO</smiles>

(B)<smiles>O=C(OOC(=O)c1ccccc1)c1ccccc1</smiles><smiles>CCCCCCCCO</smiles><smiles>O=C(O)c1ccccc1</smiles><smiles>O=C([O-])c1ccccc1</smiles><smiles>O=C1O[C@H]([C@@H](O)CO)C(=O)C1=O</smiles>

Figure 1. Decomposition of BPO by ascorbic acid (AA). The decomposition of BPO occurs in two steps: during the first step (A), AA initiates the breakage of the O-O group and generates a free radical species, which initiates the polymerization process. At the end of this step, AA is found as a radical species and can, in turn, initiate the generation of new radical species from new BPO molecules during step (B). 
$\mathrm{C}=\mathrm{O}$ stretching at $1714 \mathrm{~cm}^{-1}$. The polypropylene wells were placed on the microscope stage and the laser beam was focused on the surface of the polymer. Spectra were recorded at $4 \mathrm{~min}$ intervals for $N N$-DMPT/BPO samples and $10 \mathrm{~min}$ for AA/BPO. These values were determined by preliminary experiments.

\section{Evaluation of the kinetics of the vinyl bond conversion}

The vinyl bond conversion was determined from the intensity of the peak of the $\mathrm{C}=\mathrm{C}$ group at $1641 \mathrm{~cm}^{-1}$ according to the following equation:

$$
C_{\mathrm{V}}=1-\frac{\left(I_{\mathrm{c}=\mathrm{c}}\right)_{t}}{\left(I_{\mathrm{c}=\mathrm{c}}\right)_{t_{0}}}
$$

where $\left(I_{\mathrm{c}=\mathrm{c}}\right)_{\mathrm{t}}$ is the intensity of the $\mathrm{C}=\mathrm{C}$ group at time $t$ and $\left(I_{\mathrm{c}=\mathrm{c}}\right)_{\mathrm{t} 0}$ is the intensity of the $\mathrm{C}=\mathrm{C}$ group of the monomer at $t_{0}$.

\section{RESULTS}

The Raman spectra of the polymerization of HEMA with NN-DMPT/BPO and AA/BPO are presented in Fig. 2. The Raman spectra were very similar for both accelerator/initiator couples of polymerization. The bands obtained at 1407 and $1641 \mathrm{~cm}^{-1}$ (associated with the $\mathrm{C}=\mathrm{CH}_{2}$ stretching vibration and $\mathrm{C}=\mathrm{C}$ aliphatic stretching vibrations, respectively) vanished with the time of polymerization. This corresponded to the double-bond opening of the methacrylate group and the propagation and elongation of the polymer chains. The band at $1455 \mathrm{~cm}^{-1}$ is associated with the deformation of the $\mathrm{C}-\mathrm{H}$ group. The intensity of this band increased with time, confirming the elongation of the polymeric chain. With the AA/BPO system, a small band appeared at $1603 \mathrm{~cm}^{-1}$ at the end of the polymerization process. BPO is a strong generator of free radicals and can easily break the $\mathrm{C}=\mathrm{C}$ bond to generate a carboxylic group (Fig. 3). That molecule can be incorporated in the polymeric chain and the band appearing at $1603 \mathrm{~cm}^{-1}$ could be assigned to the stretching vibrations of the $-\mathrm{COOH}$ group. The AA/BPO system induced propagation and elongation of the polymeric chain in a manner similar to NN-DMPT/BPO.

Figure 4 represents the kinetics of the $\mathrm{C}=\mathrm{C}$ conversion. This graph shows the decrease in the number of $\mathrm{C}=\mathrm{C}$ groups during polymerization. Conversion of $\mathrm{C}=\mathrm{C}$ occurred with both accelerator/initiator couples, but differences in kinetics were evidenced. With NN-DMPT/BPO, $50 \%$ of the vinyl bonds were converted after $10 \mathrm{~min}$, whereas it took $13 \mathrm{~min}$ with the AA/BPO system. Such a difference indicates that initiation of polymerization was slower with AA/BPO than with NN-DMPT/BPO.

\section{DISCUSSION}

It is common sense to choose nontoxic molecules for preparing polymers usable as biomaterials if they do not alter
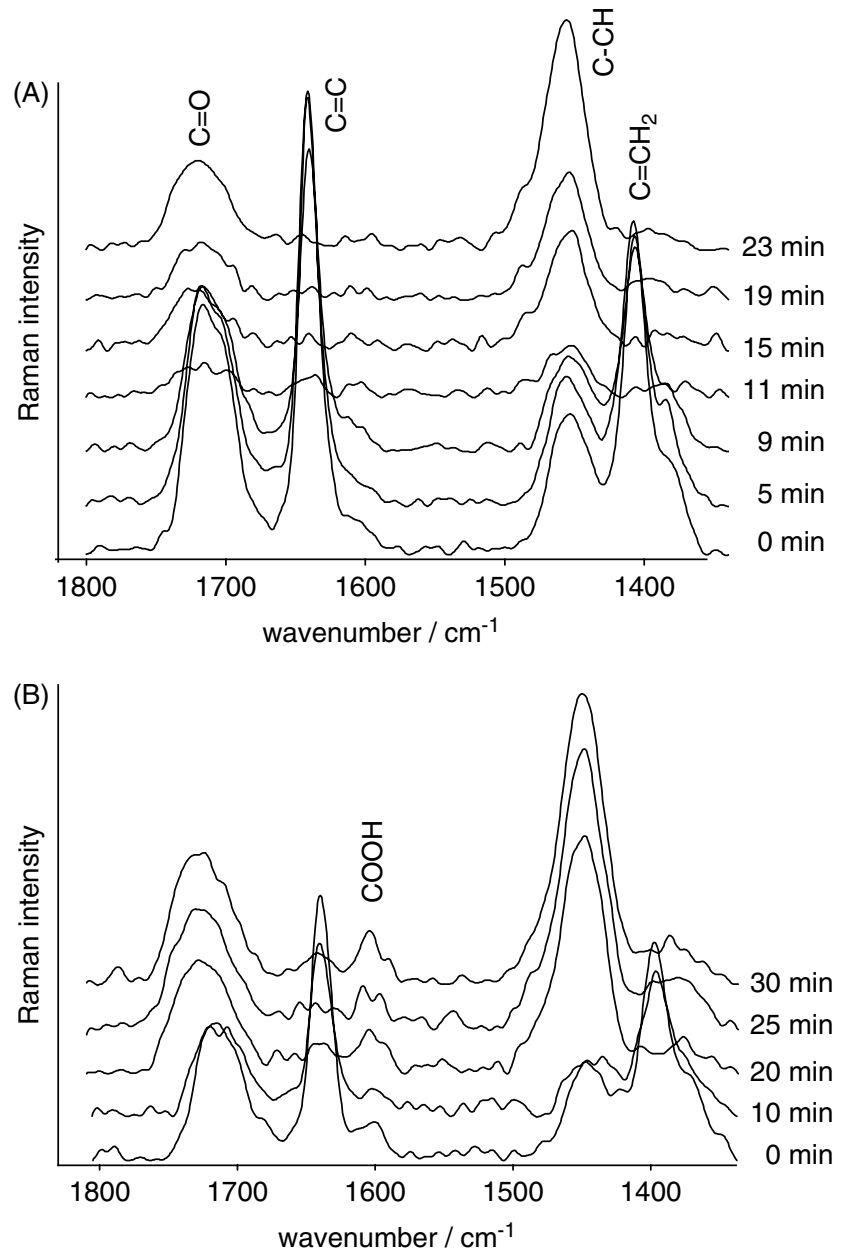

Figure 2. Raman spectra obtained during polymerization of HEMA with (A) the NN-DMPT/BPO couple, (B) with the AA/BPO couple.
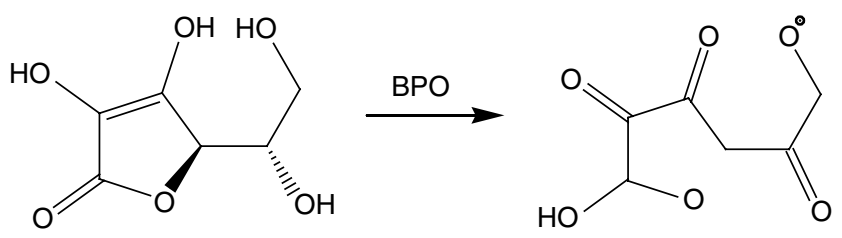

Figure 3. Transformation of AA in a carboxylic group. During the decomposition process of BPO, AA can be broken into a carboxylic acid, which is able to be incorporated in the polymer chain.

their physical properties. Toxicity is often due to unreacted molecules of the accelerator or initiator not consumed in the curing process. ${ }^{9,10}$ These degradation products of BPO fragmentation by a substituted amine (the Horner-Schlenk reaction) are known to have marked irritative properties. We have previously reported that benzoic acid and brown phenolates (end-products of BPO degradation) were produced during pHEMA preparation. ${ }^{11}$ The intradermal injection of 

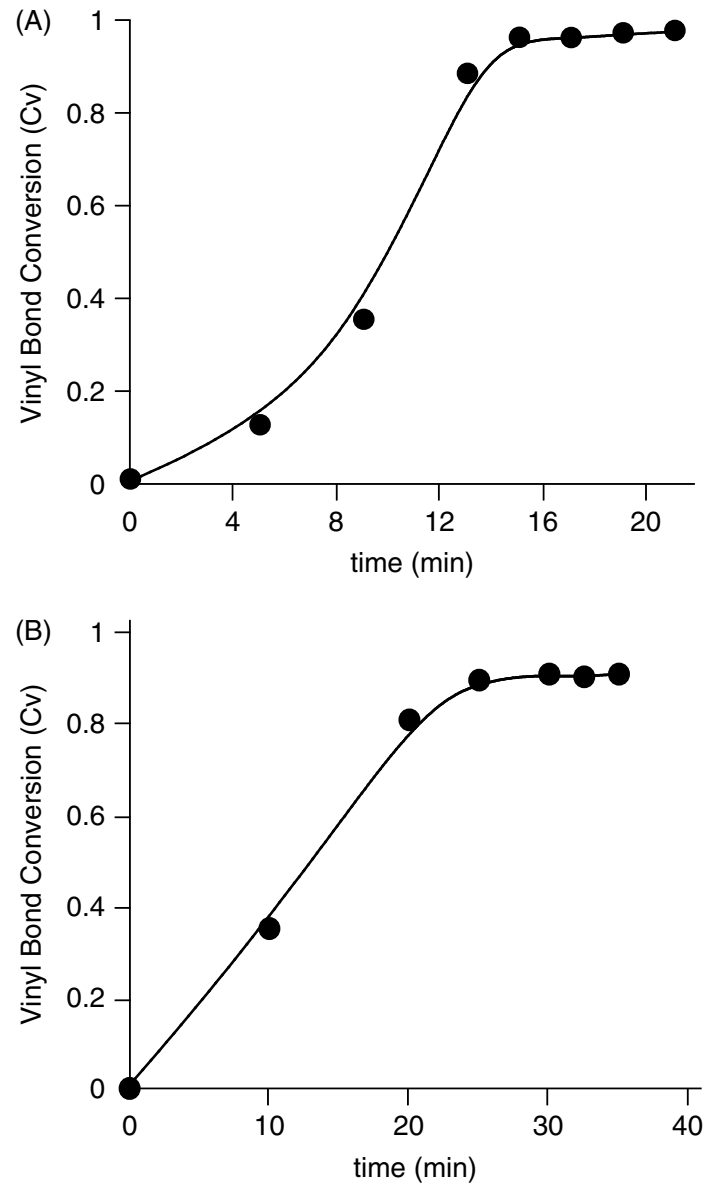

Figure 4. Conversion of the $\mathrm{C}=\mathrm{C}$ group with time of polymerization: (A) with the NN-DMPT/BPO couple; (B) with the AA/BPO couple.

sodium benzoate and other residues related to the breakdown of BPO has inflammatory properties. ${ }^{12}$ Similar findings have been reported when implanting crude pHEMA cylinders in animals. ${ }^{13}$ A promising way could be the development of new couples of accelerator/initiator with less toxicity, but little effort has been made up to now. Because pHEMA has been reported to be a suitable carrier for immobilization of proteins or drugs for the controlled release, it is likely that less toxic accelerator/initiator couples usable at low temperatures (to preserve protein properties) need to be described. ${ }^{1,4}$ Extensive rinses in saline or water are capable of removing phenolates and impurities but the immobilized active molecules are also eluted. The use of barbiturate or butazolidine has been proposed as a less toxic system in histotechnology but, curiously, this aspect has received little attention in the biomaterial literature. ${ }^{14} \mathrm{AA}$, a well-known vitamin that regulates the redox stress in cells, can initiate the decomposition of peroxides into free radicals capable of breaking the double bond of monomers, thereby initiating polymerization. ${ }^{15,16}$
Fourier-transform infrared (FT-IR) and Raman spectroscopy are powerful techniques for analyzing the chemical composition of molecules and human tissues. ${ }^{17}$ These two vibrational spectroscopy techniques are, in fact, complementary. Vibrations that are strongly active in the IR spectrum (e.g. when involving strong dipole moments) are usually weak in the Raman spectrum. Likewise, nonpolar functional group vibrations that give very strong Raman bands usually result in weak infrared signals and vice versa. However, the stretching vibrations of carbon double or triple bonds and the symmetric vibrations of aromatic groups are very strong in the Raman spectrum. Raman microscopy has also proved to be an excellent tool to follow the reaction mechanisms of polymerization with a number of monomers. ${ }^{7,18-21}$ Monitoring of the $\mathrm{C}=\mathrm{C}$ band during the entire process has been proposed to evaluate the polymerization of methyl and butyl methacrylate in bone cements used for sealing prostheses. ${ }^{8}$ The gradual intensity decrease of the $1641 \mathrm{~cm}^{-1}$ band observed in the present study confirmed the attack of the free radicals at the double bond of HEMA monomers. With the BPO/NN-DMPT system, this peak had almost disappeared after $15 \mathrm{~min}$ but it took $20 \mathrm{~min}$ to obtain the same effect with BPO/AA.

\section{CONCLUSIONS}

Although the kinetics of the curing process appeared slower than the conventional NN-DMPT/BPO system (as evaluated by the kinetic study of the vinyl bond conversion), it was suitable enough to induce a complete polymerization as evidenced by the disappearance of the $\mathrm{C}=\mathrm{CH}_{2}$ stretch at $1407 \mathrm{~cm}^{-1}$. Polymerization of methacrylic monomers can be easily followed by Raman spectroscopy. AA represents an alternative to disubstituted amines in the formulation of accelerator/initiator couples without affecting drastically the setting-up time.

\section{Acknowledgements}

G. Mabilleau received a fellowship from the French Ministry of Research and Technology and a grant from the SOCRATESERASMUS European community programme. This work was made possible by grants from Contrat de Plan Etat - Region 'Pays de la Loire', the Bioregos program and INSERM.

\section{REFERENCES}

1. Monthéard JP, Kahovec J, Chappard D. In Desk Reference of Functional Polymers; Syntheses and Applications, Chap. 5, Arshady R (ed). American Chemical Society: Washington, DC, 1997; 699 .

2. Filmon R, Baslé MF, Atmani H, Chappard D. Bone 2002; 30: 152.

3. Filmon R, Retailleau-Gaborit N, Grizon F, Galloyer M, Cincu C, Baslé MF, Chappard D. J. Biomater. Sci. Polym. Ed. 2002; 13: 1105.

4. Mabilleau G, Aguado E,Stancu IC, Cincu C, Baslé MF, Chappard D. Biomaterials 2008; 29: 1593.

5. Chappard D, Monthéard JP, Chatzopoulos M, Alexandre C. Innov. Technol. Biol. Med. 1992; 13: 322.

6. O'Neil GA, Torkelson JM. Trends Polym. Sci. 1997; 5: 349. 
7. De Santis A, Baldi M. Polymer 2004; 45: 3797.

8. Rehman I, Harper EJ, Bonfield W. Biomaterials 1996; 17: 1615.

9. Nomura Y, Teshima W, Kawahara T, Tanaka N, Ishibashi H, Okazaki M, Arizono K. J. Mater. Sci. Mater. Med. 2006; 17: 29.

10. Stea S, Granchi D, Zolezzi C, Ciapetti G, Visentin M, Cavedagna D, Pizzoferrato A. Biomaterials 1997; 18: 243.

11. Chappard D, Benascar Z, Alexandre C, Monthéard JP. J. Histotechnol. 1989; 12: 89.

12. Stol M, Cifkova I, Brynda E. Biomaterials 1988; 9: 273.

13. Cifkova I, Brynda E, Mandys V, Stol M. Biomaterials 1988; 9: 372.

14. Gerrits PO, Smid L. J. Microsc. 1983; 132: 81.

15. Antonucci JM, Grams CL, Termini DJ. J. Dent. Res. 1979; 58: 1887.
16. Larpent C, Bernard E, Richard J, Vaslin S. Macromolecules 1997; 30: 354 .

17. Salzer R, Steiner G, Mantsch HH, Mansfield J, Lewis EN. Fresenius J. Anal. Chem. 2000; 366: 712.

18. Bersani D, Lottici PP, Tosini L, Montenero A. J. Raman Spectrosc. 1999; 30: 1043.

19. Edwards HGM, Johal KS, Johnson AF. Vib. Spectrosc. 2006; 41: 160.

20. Krammer S, Albinsky K, Sandner B, Wartewig S. Polymer 1999; 40: 1131.

21. Ozpozan T, Schrader B, Keller S. Spectrochim. Acta, Part A 1997; 53: 1. 